\title{
Web-Based Animation Video for Student Environmental Education at Elementary Schools
}

\author{
https://doi.org/10.3991/ijim.v15i11.22023 \\ Desy Safitri ( $\left.{ }^{\bowtie}\right)$ Ika Lestari, Arifin Maksum, \\ Nurzengky Ibrahim, Arita Marini \\ Universitas Negeri Jakarta, Jakarta, Indonesia \\ desysafitri@unj.ac.id \\ Musril Zahari \\ Sekolah Tinggi Ilmu Ekonomi Indonesia, Jakarta, Indonesia \\ Rossi Iskandar \\ Universitas Trilogi, Jakarta, Indonesia
}

\begin{abstract}
Following the globalization era, the educational system needs technology to prepare the 21 st century generation. Students often feel bored with the subject matter delivered monotonously. Technology application can make alternative teaching methods being more interactive to invite students to focus more on learning. This technological advance can transmit the concept visually and allow the students to assimilate the information delivered rather than memorize it effectively. Web-based animation videos as a learning innovation enable learning more enjoyable and students eager to receive subject matter. The web-based animation video is suitable for students in the globalization era in achieving students' thinking and learning skills. The research objective is to know the effectiveness of using animation videos based on the web in elementary school students' environmental education. This research was conducted in 2020. This research population is elementary school students in the fifth grade at Matraman sub-district in the 2019/2020 academic year in East Jakarta in Indonesia with simple random sampling using the Slovin Formula sampling technique. The data analysis technique applied in this research is the Independent Sample t-Test. In conclusion, it is highlighted that web-based animation videos are used for environmental education at elementary school students.
\end{abstract}

Keywords - The 21 st century generation, web-based animation video, environmental education 


\section{Introduction}

Current technology advancement has vastly improved life quality. Protection of natural resources is crucial for the existence of humanity. Schools must raise awareness of the environment, open their horizons, interact, and behave responsibly. Environmental education is essential to foster new attitudes towards the earth's components involving water, air, animals, and plants, demanding comprehensive thinking. Environmental education must be done effectively in schools to understand nature with great compassion and respect for fellow creatures.

Studies discussing environmental education have been conducted, specifically related to environmental awareness. However, other research is found to have different findings. Some studies found that environmental education can improve student environmental attitudes, leading to positive environmental behavior [1-2]. In line with these findings, environmental education can enhance the environmental moral level [3]. A similar study found that environmental education significantly correlates with environmental ethics and ecological literacy [4-5]. In line with the previous studies, this research presents that the learners having the upper level of comprehension about environmental education have more favorable ecological attitudes than those with lower ones, a more profound control supporting natural word, and sustainable development [6]. In these studies, environmental education prepared students to behave on behalf of the environment, directly impacting environmental quality and achievement in conservation outcomes. These studies also show that environmental education has been highlighted as a relevant tool to transfer information for the students, including knowledge, experience, values, and practices supporting environmentally-related awareness. Environmental education refers to actions that contribute to the students assimilating concepts and practical knowledge, assisting them in environmental problem awareness, and supporting contribution to safeguarding the environment. However, other studies found weak evidence about nature's instruction promoting a more significant surroundings consciousness intensity.

Studies investigating the benefits of using technology in the classroom have increased in the last few years. Their collective findings reported that the application of technology in education could improve student anger management skills, enhance the teaching-learning process's effectiveness, increase academic achievement, and foster positive behavior [7-13]. Other studies presented that the application of technology can raise problem-solving capability, heighten computational thinking competency, upgrade writing ability, be adopted due to usefulness and easiness, and boost motivation [14-19]. The advantages of using technology in education in the cognitive and affective domain are seen in the current studies` interests.

Regarding academic contexts, technology has been proven to engage the various student learning approaches in terms of accommodating the student learning preferences to change easily [20]. There is empirical evidence showing that technology can enhance students by giving a pleasant experience of learning and analytical abilities due to exposure to animation and simulations provided. However, this empirical evidence was not related to environmental education. Therefore, this 
research combines technology with environmental education. This research developed a web-based animation video and learned how to use this technology in student environmental education at elementary schools in East Jakarta in Indonesia. The main research question was: "Did web-based animation video application significantly affect environmental education at elementary schools in East Jakarta in Indonesia?". This investigation attempted to respond to research problems as follows:

a) How is animation video attached on the web for students at elementary schools?

b) Was there any differentiation on the preliminary test and final test of average student environmental education grades through web-based animation video application at elementary schools?

\subsection{Educational application design}

Adopting technology depends on the effectiveness of using this technology in education to improve information literacy. Previous research proved that developmentally appropriate technology stimulated student computational thinking concept fluency and the development of student interests in computing at the beginning period $[15,21]$. Other findings stated that applying educational application affected understanding the concept and knowledge, enhancing the learning process, and increasing student learning outcomes [22-25]. These studies indicate that technology enhances the teaching-learning process, student motivation, engagement, and academic achievement. There has been some debate about educational technology application is practical or not. Students accept social media more enthusiastically as an instrument for social relationships than for studying [26].

\subsection{Web-based animation video}

The application of animated video for education has been shown in several studies to improve students' achievement [27] and develop student motivation [28]. Hence, in these studies, through an animated educational video, students regarded themselves as engaged in a more central role in reciprocal communication in class, became matted with benefit in learning, and gave exceptional value to technology during the teaching and learning process.

There are many findings regarding the impact of a website application. These studies have shown that using the website attributes to shape positive behavior, acquire knowledge, and attempt to find information and enhance academic achievement [13,29-31]. Other findings stated that using the web can stimulate learning motivation, develop literacy, improve student activity, intensify reading apprehension and learning endurance, and increase student engagement [32-38]. In comparison, another study found that websites reduced student social life [30]. 


\subsection{Environmental education}

Some indicators are required to measure student learning outcomes related to environmental education. Many studies about predictors of environmental education were carried out. Some studies found a model through Structural Equation Modeling that environmental education is predicted by fulfilling individual curiosity about nature, enhancing awareness of the environment, and encouraging pro-preservation principles [39-40]. In addition to this, they provided some indicators influencing those three dimensions. Adequately meeting natural curiosity is stimulated by knowledge improvement about nature, positive attitude toward the environment, skill improvement about the environment, and environmental curiosity fulfilled. Awareness increase of nature is influenced by concern about taking care of the environment well, not to ruin the environment, not to exploit the environment, and to feel concerned about environmental cleanliness. Another study has highlighted the intensification of environmental education due to some treatment conducted. Environmental education's effectiveness can be stimulated by reciprocal learning related to environmental issues, including means of effectively dealing with environmental problems comprising air pollution, detrimental effects of mangrove forest, coastal destruction, and reduction in ozone quantity [41].

There is much information discovered related to the impacts of environmental education. Some studies have presented that environmental education contributes to promoting a higher ecological awareness level, environmental care attitude, environmental knowledge, and skill [42-46]. Many different studies examined environmental education stimulated environmental ethics and environmental literacy, supported environmentally friendly behavior in the community, maintained environmental quality, established environmental experience and value, realized environmental protection, and achieved sustainable development of the natural environment [47-55]. These studies present a range of intended results for environmental education's role for knowledge, attitudes, and behaviors to develop and support environmental actions positively impacting general environmental excellence of standard and preservation consequence.

This research aims to focus on developing web-based animation videos and highlights environmental issues in them compared to the previous work. This research's contribution is: (1) developing web-based animation video that is a combination between using the web and animated video as conducted in the previous research, (2) effectiveness of web-based animation video to improve environmental education.

\section{Method}

This research was conducted in 2019 at elementary schools at the sub-district of Matraman in East Jakarta in Indonesia. 


\subsection{Design of research}

A design of quasi-experimental was applied in this research. A preliminary test was given to the experimental and control group. Both groups selected randomly got different treatment. The experimental group used animation videos based on the web, and the control group used the conventional method. The experimental technique applied in this research is presented in Table 1.

Table 1. The research technique of web-based animation videos effectiveness

\begin{tabular}{|l|l|l|l|}
\hline E & O1 & X1 & O2 \\
\hline C & O3 & X2 & O4 \\
\hline
\end{tabular}

$\begin{array}{lll}\text { Notes: } & & \\ \mathrm{E} & = & \text { Experiment group } \\ \mathrm{C} & = & \text { Control group } \\ \mathrm{O} 1 & = & \text { Initial test before treatment in the experimental group } \\ \mathrm{O} 2 & = & \text { Final test after treatment in the experimental group } \\ \mathrm{O} 3 & = & \text { Initial test before treatment in the control group } \\ \mathrm{O} 4 & = & \text { Final test after treatment in the control group } \\ \mathrm{X}_{1} & = & \text { application of web-based animation videos } \\ \mathrm{X}_{2} & = & \text { application of the conventional method }\end{array}$

\subsection{Population and sample}

This research population consists of 948 students grade five at elementary school students in the academic year 2019/2020 at sub-district of Matraman in East Jakarta located in Indonesia. This research used simple random sampling with the Slovin Formula sampling technique consisting of 137 students for the experimental and control group.

\subsection{Research instruments}

The test instrument was used at pretest and posttest with identical question characteristics on each test related to environmental education, providing adequate information for the student's natural curiosity, extending environmental awareness, and strengthening pro-conservation values. The pretest was given before the two groups were subjected to web-based animation videos for the experimental and conventional methods was given for the control group. Posttest was given after treatment was applied to the experimental group and the control group. The next step was to compare the pretest results to ones of the posttest for both groups.

\subsection{Data analysis}

A test for normality was carried out as a prerequisite for the analysis. The normality test in this study used the Kolmogorov-Smirnov test to determine whether the data distribution of experimental and control groups was normally distributed or not. The data is normally distributed if the coefficients of the asymptotic distribution 
of Kolmogorov-Smirnov test output are more significant than the specified alpha value of 0.05 . A homogeneity test was utilized to determine whether the data groups coming from a homogeneous population or not. The test of homogeneity in this research used Levene's test. The data is homogeneous if Levene's test output coefficient is more significant than the pre-specified alpha level of 0.05 .

Analyzing data in this research used Independent Sample t-Test Criteria as an inferential statistical test with the value set at 0.05 . Rejection of the null hypothesis was done if the result is less than a $5 \%$ chance. On the contrary, failing to reject the null hypothesis was concluded if the test statistic is larger than the critical value.

\section{$3 \quad$ Results and Discussions}

\subsection{Web-based animation video}

Some descriptions about web-based animation video resulted as in the following. The product created in this research is called Web-Based Animation Video for Student Environmental Education. The creation process of animation videos in this research used Adobe Illustrator to create characters, Adobe After Effect to form animation, and Adobe Premiere to prepare the videos. This animation video is a combination of animation created, and audio required. Developing web-based animation video was started by choosing wix.com as web home and pressing the button 'start now.' It appeared on the sign-up page to be registered as a new user. Choosing a category of the web is the next step to describe web development. Page of Wix editor's selection was to edit web parts. The selected template can be changed suitably with moving photos, text color changing, and google maps to have web accessories. Web pages can be added adjusted with user needs. Subpages can be added appearing in the dropdown menus.

The web-based animation video's main page appears with having a structure of the title of a 2-dimension (D) animation website completed with the research leader's name. There is a logo of Universitas Negeri Jakarta (UNJ) to the right of the header. This page is equipped with three menu bars located below the UNJ logo. The introduction menu is immediately presented on this main page. Furthermore, there is a 2D animation video menu in the form of a dropdown menu. If the mouse cursor hovers over the menu, it will automatically issue other menus in the form of a dropdown list. The following menu bar is the information menu. Clicking this menu will take the user to another page. This main page is also equipped with all animated videos seen at the bottom of the page.

The page for each video is made separately by the menu's location in the top dropdown menu. It has five different video page sections in the following order: climate change, mangrove forest, waste recycling, biodiversity, and ozone depletion animated video page (Figures 1 and 2). The first animated video page for climate change is about human anthropogenic activities disrupting organic circulations and creating an extended period of alterations in national and worldwide weather. Users 
can directly watch the animated video for climate change because it has an auto-play feature or plays itself.

The second animated video page tells about mangrove forests growing in places with many muds and organic matter accumulation such as swamps and brackish water. The mangrove forests are affected by tides and have physical, chemical, biological, ecological, economic, and social functions useful for human welfare. This animated video for mangrove forests can be watched by the user directly because the video has an autoplay feature of plays itself.

The third animated video page is about waste recycling using the reuse-reducerecycle principle overcoming environmental pollution and improving environmental health. Users can watch the animated video of the waste directly because it has an autoplay feature of plays itself.

The fourth animated video page is about biodiversity determined by geography, topography, climate, rainfall, flora, and fauna being beneficial to human health and well-being. Users can watch the animated video of biodiversity because it has an autoplay feature.

The fifth animated video page is about ozone depletion having direct and indirect impacts on the earth's life caused by anthropogenic activities. The message from this video is that we must reduce anthropogenic activities on land to conserve the environment. Users can watch the animated video of ozone depletion because the video has an autoplay feature.

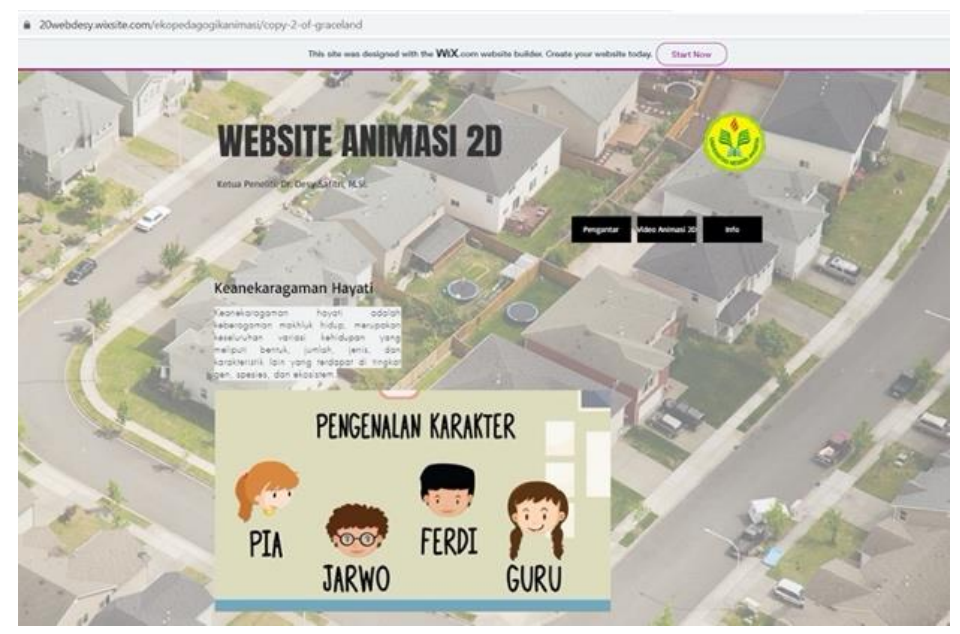

Fig. 1. Biodiversity animated video page 


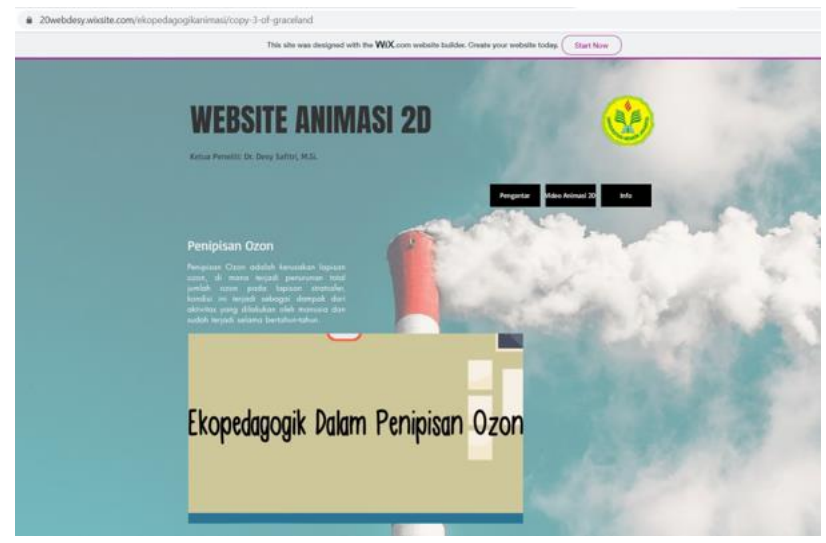

Fig. 2. Ozone depletion animated video page

\subsection{The effect of the web-based animation video application on student environmental education}

Based on normality test results in Table 2, it can be seen for sample 137 students for control and experiment group. Normal parameters measured by mean as the central tendency of the distribution and standard deviation as variability measurement reaching 36.234 and 5.008 for the pretest control group, 36.365 and 5.162 for pretest experiment group, 49.358 and 2.841 for the posttest control group, 49.883 and 2.665 for posttest experiment group. Table 2 shows that in the experimental group, the Asymp. Sig. (2-tailed) Kolmogorov-Smirnov value obtained in pretest is 0.059 larger than 0.05 and in posttest is 0.154 larger than 0.05. In the control group, the Asymp. Sig. (2-tailed) Kolmogorov-Smirnov value obtained in pretest is 0.052 larger than 0.05 , and in posttest is 0.056 larger than 0.05 . Kolmogorov-Smirnov calculated value indicated by the absolute value in the most extreme differences for the experimental group in pretest and posttest reached 1.327 and 1.132 and control group in pretest and posttest attained 1.353 and 1.336 less than 0.116 as the Kolmogorov-Smirnov table value. These results indicate that the pretest and posttest data in experimental and control groups are normally distributed as a prerequisite for statistical analysis. It means that it can improve the objectivity and avoid bias in this research. 
Table 2. Normality test

\begin{tabular}{|c|c|c|c|c|c|}
\hline \multicolumn{2}{|c|}{$\begin{array}{c}\text { One-Sample Kolmogorov- } \\
\text { Smirnov Test }\end{array}$} & \multicolumn{2}{|c|}{ Posttest } & \multicolumn{2}{|c|}{ Pretest } \\
\hline & & $\begin{array}{c}\text { Experimental } \\
\text { group }\end{array}$ & Control group & $\begin{array}{c}\text { Experimental } \\
\text { group }\end{array}$ & Control group \\
\hline \multicolumn{2}{|l|}{$\mathrm{N}$} & 137 & 137 & 137 & 137 \\
\hline \multirow{2}{*}{$\begin{array}{l}\text { Normal } \\
\text { Parameters }\end{array}$} & Mean & 49.883 & 49.358 & 36.365 & 36.234 \\
\hline & Std. Deviation & 2.665 & 2.841 & 5.162 & 5.008 \\
\hline \multirow{3}{*}{$\begin{array}{l}\text { Most Extreme } \\
\text { Differences }\end{array}$} & Absolute & .097 & .114 & .113 & .116 \\
\hline & Positive & .097 & .096 & .110 & .112 \\
\hline & Negative & -.072 & -.114 & -.113 & -.116 \\
\hline \multicolumn{2}{|c|}{ Kolmogorov-Smirnov Z } & 1.132 & 1.336 & 1.327 & 1.353 \\
\hline \multicolumn{2}{|c|}{ Asymp. Sig. (2-tailed) } & .154 & .056 & .059 & .052 \\
\hline \multicolumn{2}{|c|}{ a. Test distribution is Normal. } & & & & \\
\hline
\end{tabular}

Table 3 shows that the Levene's test with degrees of freedom $(\mathrm{df} 1)=1$ and $\mathrm{df} 2=$ 272 in pretest are 0.732 larger than 0.05 and posttest is 0.807 larger than 0.05 . In addition to this, Levene test statistics reach 0.117 for pretest and 0.060 for posttest, which is less than the critical value. These results point out that experimental and control group data are homogeneous, meaning that variance level in these groups is constant across the sample so that probability value is trustworthy and measurement in the different test is produced accurately.

Table 3. Homogeneity of variances test

\begin{tabular}{|c|c|c|c|c|}
\hline Levene Statistic & df1 & df2 & Sig. \\
\hline \multicolumn{6}{|c|}{ Pretest } \\
\hline .117 & 1 & & 272 & .732 \\
\hline \multicolumn{7}{|c|}{ Posttest } \\
\hline .060 & 1 & & 272 & .807 \\
\hline
\end{tabular}

Table 4 shows that the t-test of pretest data with $\mathrm{df}=272$ in experimental and control groups with sig value 2-tailed is 0.831 larger than 0.05 . Besides that, the calculated t-values arrive at 0.214 less than the t-table value. These t-test results indicate that failing to reject the null hypothesis, meaning no significant difference between the pretest of experimental and control groups.

Table 4. Results of t-test in pretest of experimental and control groups

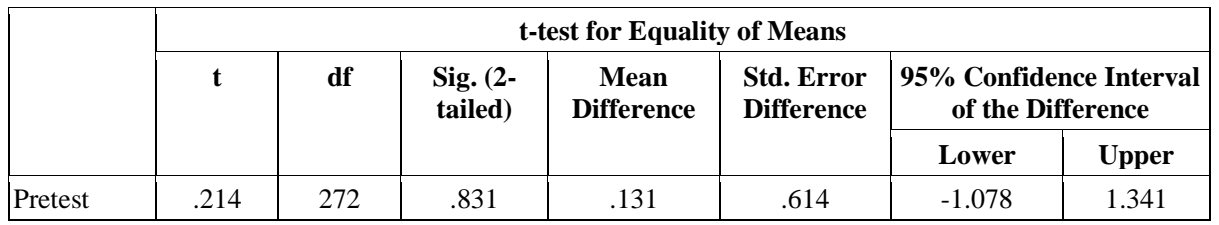


Table 5 displays that the t-test of posttest data with $\mathrm{df}=272$ in experimental and control groups with sig value 2 -tailed is 0.006 smaller than 0.05 . In addition to this, the calculated t-values for posttest of experimental and control groups achieve 1.622 more significant than the t-test value. These t-test results indicate that the null hypothesis is rejected, showing a significant difference between the posttest of experimental and control groups.

Table 5. Results of t-test in posttest of experimental and control groups

\begin{tabular}{|l|c|c|c|c|c|c|c|}
\hline & \multicolumn{9}{|c|}{ t-test for Equality of Means } \\
\cline { 2 - 7 } & $t$ & $d f$ & $\begin{array}{l}\text { Sig. (2- } \\
\text { tailed) }\end{array}$ & $\begin{array}{c}\text { Mean } \\
\text { Difference }\end{array}$ & $\begin{array}{l}\text { Std. Error } \\
\text { Difference }\end{array}$ & $\begin{array}{c}\text { 95\% Confidence Interval of } \\
\text { the Difference }\end{array}$ \\
\cline { 5 - 8 } & & & & & Lower & Upper \\
\hline Post-test & 1.622 & 272 & .006 & .54015 & .33291 & -.11527 & 1.19556 \\
\hline
\end{tabular}

Table 4 and 5 points out that the application of web-based animation video positively affects environmental education for elementary school students grade five at elementary school students in the academic year 2019/2020 at the sub-district of Matraman in East Jakarta in Indonesia. The research results agree that implementing the animation video in learning can enhance student positive experiences and learning gain [27,30]. This tool can keep students away from memorizing lessons but understanding them deeply. It can reduce the concept abstraction to be more concrete so that learning is more meaningful for students. It can also improve the student motivation to analyze information obtained with great curiosity. In addition to the impact of animation video, these findings also align with the study found that website application can get the knowledge and have an effort to seek some information [29], and improve student learning outcomes [30]. Animation video application combined with the website as technology advancement applied in environmental education. Similar to other studies' findings, individual natural curiosity satisfaction, environmental awareness, and pro-conservation values encouragement stimulating environmental education [39][40] can be enhanced through web-based animation videos.

\section{Conclusion}

It can be concluded that there is a positive effect of web-based animation video applications on environmental education for elementary school students. Web-based animation video makes it the student easier to understand the teaching material about the environment given. This tool improves the students' learning experiences to be more motivated to learn about environmental conservation. The students are more aware of solving environmental problems, including air pollution, mangrove forest damage, coastal erosion, and ozone depletion.

Further research can be done to use this tool to enhance student behavior related to environmental conservation at elementary schools. This research aims to provide 
elementary school teachers with information to improve their competencies to use technological advancement to maintain environmental quality towards sustainability development. This research's limitations include the scope of research only covering students at elementary schools in East Jakarta. Further research should relate to all regions in Jakarta and other provinces in Indonesia to understand the impact of technology advancement on environmental education.

\section{Acknowledgement}

This research was funded by Universitas Negeri Jakarta in the scheme of competitive research grants in 2020. Researchers are grateful for students who are willing to be involved in this research.

\section{$6 \quad$ References}

[1] Ardoin, N., M., Bowers, A., W. Environmental education outcomes for conservation: A systematic review. Biological Conservation, 241, 1-13, 2020. https://doi.org/10.1016 /j.biocon.2019.108224.

[2] Gkiolmas, A., Dimakos, C., Chalkidis, A., Stoumpa, A. An environmental education project that measures particulate matter via an Arduino interface. Sustainable Futures, 2, 18, 2020. https://doi.org/10.1016/i.sftr.2020.100027.

[3] Liu, Q., Cheng, Z., Chen, M. Effects of environmental education on environmental ethics and literacy based on virtual reality technology. The Electronic Library, 37(6), 860-877, 2019. https://doi.org/10.1108/EL-12-2018-0250.

[4] Collado, S., Rosa, C. D., and Corraliza, J., A. The effect of a nature-based environmental education program on children's environmental attitudes and behaviors: A randomized experiment with primary schools. Sustainability, 12, 1-12, 2020. https://doi.org/10.3390/su12176817.

[5] Edsand, H., E., Broich, T. The impact of environmental education on environmental and renewable energy technology awareness: Empirical evidence from Colombia. International Journal of Science and Mathematics Education, 18, 611-634, 2020. https://doi.org/10.1007/s10763-019-09988-x.

[6] Li, Y. Study of the effect of environmental education on environmental awareness and environmental attitude based on environmental protection law of the people's Republic of China. Eurasia J Math Sci Tech Ed, 14(6), 2277-2285, 2018. https://doi.org/10.29333 lejmste/86214.

[7] Sadagheyani, H., E., Tatari, F., Raoufian, H., Salimi, P., and Gazerani, A. The effect of multimedia-based education on students' anger management skill. Educacion Medica, 1575-1813, 2020. https://doi.org/10.1016/j.edumed.2020.09.0201575-1813.

[8] Eppard, J., Hojeij, Z., Ayber, P., O., Helder, M., R., Baroudi, S. Using mobile learning tools in Higher Education: A UAE case. International Journal of Interactive Mobile Technologies, 13(11), 51-69, 2019, https://doi.org/10.3991/ijim.v13i11.10823.

[9] Mun, S., H., Abdullah, A., H., Mokhtar, M., Ali, D., F., Jumaat, N., F., Ashari, Z., M., Samah, N., A. Active learning using digital smart board to enhance primary school students' learning. International Journal of Interactive Mobile Technologies, 13(7), 4-16, 2019, https://doi.org/10.3991/ijim.v13i07.10654. 
[10] Al Khateeb, M., A. Effect of teaching geometry by slow-motion videos on the $8^{\text {th }}$ graders' achievement. International Journal of Interactive Mobile Technologies, 14(18), 57-67, 2020, https://doi.org/10.3991/ijim.v14i18.12985.

[11] Mendez, D. Smartphones in order to measure the correlation between speed of reading and logical reasoning of future preschool teachers. International Journal of Interactive Mobile Technologies, 12(4), 72-85, 2018, https://doi.org/10.3991/ijim.v12i4.9202.

[12] El-Sofany, H., F. The effectiveness of using mobile learning techniques to improve learning outcomes in Higher Education. International Journal of Interactive Mobile Technologies, 14(8), 4-18, 2020, https://doi.org/10.3991/ijim.v14i08.13125.

[13] Tawafak, R., M. Impact of technologies during covid-19 pandemic for improving behavior intention to use E-learning. International Journal of Interactive Mobile Technologies, 15(1), 184-198, 2021, https://doi.org/10.3991/ijim.v15i01.17847.

[14] Al-Khateeb, M., A. The effect of teaching mathematical problems solving through using mobile learning on the seventh-grade students' ability to solve them in Jordan. International Journal of Interactive Mobile Technologies, 12(3), 178-191, 2018, https://doi.org/10.3991/ijim.v12i3.8713.

[15] Bedar, R., A., H. The effect of using STEAM approach on developing computational thinking skills among high school students in Jordan. International Journal of Interactive Mobile Technologies, 14(14), 80-94, 2020, https://doi.org/10.3991/ijim.v14i14.14719.

[16] Rong, L., P. Digital storytelling as a creative teaching method in promoting secondary school students' writing skills. International Journal of Interactive Mobile Technologies, 13(7), 117-128, 2019, https://doi.org/10.3991/ijim.v13i07.10798.

[17] Jaradat, M., I., R., M., Imlawi, J., M., Al-Mashaqba, A., M. Investigating the moderating effects of self-efficacy, age and gender in the context of nursing mobile decision support systems adoption: A developing country perspective. International Journal of Interactive Mobile Technologies, 12(2), 113-129, 2018, https://doi.org/10.3991/ijim.v12i2.8081.

[18] Mendez, D., Mendez, M., Anguita, J. Motivation of 14 year-old students using tablet, compared to those using textbooks and workbooks. International Journal of Interactive Mobile Technologies, 12(4), 86-96, 2018, https://doi.org/10.3991/ijim.v12i4.9203.

[19] Lestari, I., Maksum, A., Kustanti, C. Mobile learning design models for State University of Jakarta, Indonesia. International Journal of Interactive Mobile Technologies, 13(9), 152171, 2019, https://doi.org/10.3991/ijim.v13i09.10987.

[20] Alsobhi, A., Y., Alyoubi, K., H. Learning Styles and Dyslexia Types: Understanding their relationship and its benefits in adaptive e-learning systems. International Journal of Interactive Mobile Technologies, 14(15), 25-43, 2020, https://doi.org/10.3991 lijim.v14i15.16129.

[21] Papadakis, S. Apps to promote computational thinking concepts and coding skills in children of preschool and pre-primary school age. Mobile Learning Applications in Early Childhood Education, 101-121, 2020, https://doi.org/10.4018/978-1-7998-1486-3.ch006

[22] Dorouka, P., Papadakis, S., Kalogiannakis, M. Tablets and apps for promoting robotics, mathematics, STEM education and literacy in early childhood education. International Journal of Mobile Learning and Organisation, 14(2), 255-274, 2020, https://doi.org/10.1504/IJMLO.2020.106179.

[23] Kalogiannakis, M., Ampartzaki, M., Papadakis, S., \& Skaraki, E. Teaching natural science concepts to young children with mobile devices and hands-on activities. A case study. International Journal of Teaching and Case Studies, 9(2), 171-183, 2018, https://doi.org/10.1504/IJTCS.2018.090965. 
[24] Vagg, T., Balta, J. Y., Bolger, A., \& Lone, M. Multimedia in education: What do the students think? Health Professions Education, 6, 325-333, 2020. https://doi.org/10.1016/j.hpe.2020.04.011.

[25] Kalogiannakis, M., Papadakis, S., and Zourmpakis, A., I. Gamification in science education. A systematic review of the literature. Education Sciences, 11(1), 1-36, 2021, https://doi.org/10.3390/educsci11010022.

[26] Ogbonnaya, U., I. Adoption and perceived usefulness of social media by pre-service teachers in Nigeria. International Journal of Interactive Mobile Technologies, 13(6), 52-67, 2019, https://doi.org/10.3991/ijim.v13i06.10299.

[27] Papadakis, S. Tools for evaluating educational apps for young children: A systematic review of the literature. Interactive Technology and Smart Education, 2020, https://doi.org/10.1108/ITSE-08-2020-0127.

[28] Osuafor, A., Maureen, N., Anusiuba, I., O. Effects of animated media instructional strategies on achievement and retention of secondary school students in computer studies. International Journal of Scientific and Engineering Research, 10(6), 1692-196, 2019, https://www.researchgate.net/publication/334836232.

[29] Egounleti, P., M., Hindeme, U., O., S., Sonou, T., K. Examining the impacts of cartoons on motivating EFL beginner students to speak English language in Beninese Secondary Schools: The case study of some secondary schools in the Atlantic Region. American Scientific Research Journal for Engineering, Technology, and Sciences (ASRJETS), 50(1),155-180, 2018, https://core.ac.uk/download/pdf/235050717.pdf.

[30] Ayittey, A., Nyarko, E., A., Onuman, F. Impact of multimedia instruction in Biology on senior high school students' achievement. Computer Science and Information Technology, 7(5), 162-173, 2019, https://doi.org/10.13189/csit.2019.070502.

[31] Zhang, Y., Qin, X., Ren, P. Adolescents' academic engagement mediates the association between internet addiction and academic achievement: The moderating effect of classroom achievement norm. Computers in Human Behavior, 89, 299-307, 2018, https://doi.org/10.1016/j.chb.2018.08.018.

[32] Lai, C., H., Jong, B., S., Hsia, Y., T. Using reminder tools to increase learning motivation: A comparison of mobile devices, email and e-learning platforms. International Journal of Interactive Mobile Technologies, 14(19), 82-96, 2020, https://doi.org/10.3991 lijim.v14i19.12519.

[33] Eeva, N. Dynamics between disturbances and motivations in education mobile games. International Journal of Interactive Mobile Technologies, 12(3), 120-141, 2018,

[34] Stathopoulou, A. Mobile assessment procedures for mental health and literacy skills in education. International Journal of Interactive Mobile Technologies, 12(3), 21-37, 2018,

[35] Saraubon, K. Learning media repository and delivery system for smart classrooms using IoT and mobile technologies. International Journal of Interactive Mobile Technologies, 13(2), 66-77, 2019, https://doi.org/10.3991/ijim.v13i02.9941.

[36] Bursali, H., Yilmaz, R., M. Effect of augmented reality applications on secondary school students' reading comprehension and learning permanency. Computers in Human Behavior, 95, 126-135, 2019, https://doi.org/10.1016/j.chb.2019.01.035.

[37] Dascalu, M., D., Ruseti, S., Dascalu, M., McNamara, D., S., Carabas, M., Rebedea, T., Matu, S., T. Before and during COVID-19: A cohesion network analysis of students' online participation in moodle courses. Computers in Human Behavior, 2021, https://doi.org/10.1016/j.chb.2021.106780.

[38] Ding, Lu. Applying gamifications to asynchronous online discussions: A mixed methods study. Computers in Human Behavior, 91, 1-11, 2019, https://doi.org/10.1016 /j.chb.2018.09.022. 
[39] Safitri, D., Umasih, Yunaz, H., Marini, A., \& Wahyudi, A. Model of environmental education. International Journal of Control and Automation, 12(4), 49-55, 2019. http://sersc.org/journals/index.php/IJCA/article/view/515/471.

[40] Safitri, D., Yunaz, H., Umasih, Marini, A., \& Wahyudi, Effect of environmental education on Ecotourism: Evidence from Jakarta. International Journal of Control and Automation, 12(4), 37-48, 2019. http://sersc.org/journals/index.php/IJCA/article/view/510/466

[41] Safitri, D., Nuraini, S., Rihatno, T., Kaban, S., Marini, A., \& Wahyudi, A. Improving student learning outcomes through reciprocal learning in environmental education course. International Journal of Advanced Science and Technology, 29(8s), 190-193, 2020. http://sersc.org/journals/index.php/IJAST/article/view/10439/5623.

[42] Edsand, H., E., Broich, T. The impact of environmental education on environmental and renewable energy technology awareness: Empirical evidence from Colombia. International Journal of Science and Mathematics Education, 18, 611-634, 2020, https://doi.org/10.1007/s10763-019-09988-x.

[43] Li, Y. Study of the effect of environmental education on environmental awareness and environmental attitude based on environmental protection law of the people's Republic of China. Eurasia Journal of Mathematics, Science and Technology Education, 14(6), 22772285, 2018, https://doi.org/10.29333/ejmste/86214.

[44] Tsantopoulos, G., Skanavis, C., Bantoudi, F., Petkou, D., Dalamagkidou, A. Assessing preference of informal environmental education sources for Greek primary school students. International Journal of Environmental \& Science Education, 13(3), 357-371, 2018, http://www.ijese.net/makale_indir/IJESE_2045_article_5b3680078af8e.pdf

[45] Gkiolmas, A., Dimakos, C., Chalkidis, A., Stoumpa, A. An environmental education project that measures particulate matter via an Arduino interface. Sustainable Futures, 2, 2020, https://doi.org/10.1016/j.sftr.2020.100027

[46] Sahabi, S., W., Hite, R., Cao, C., A. The effect of globally collaborative project based learning on secondary students' achievement in advanced placement environmental science. International Journal of Environmental \& Science Education, 13(10, 903-921, 2018, http://www.ijese.net/makale_indir/IJESE_2097_article_5c23d56b5802e.pdf

[47] Liu, Q., Cheng, Z., and Chen, M. Effects of environmental education on environmental ethics and literacy based on virtual reality technology. The Electronic Library, 37(5), 860877, 2019, https://doi.org/10.1108/EL-12-2018-0250

[48] Liu, Q., Gong, D., Chen, M. Applying virtual reality to study the effects of environmental education on college students' ethics and environmental literacy. Eurasia Journal of Mathematics, Science and Technology Education, 14(6), 2255-2263, 2018, https://doi.org/10.29333/ejmste/85937

[49] Merino, A., Valor, C., \& Redondo, R. Connectedness is in my character: The relationship between nature relatedness and character strengths. Environmental Education Research, 26(12),1707-1728,2020,https://www.tandfonline.com/doi/ pdf/10.1080/13504622.2020.1825630

[50] Liu, S., Hou, Q., Guo, L. Based on environmental experience to discuss the effect of environmental education on environmental value. Ekoloji, 27(106), 991-997, 2018, http://www.ekolojidergisi.com/article/based-on-environmental-experience-to-discuss-theeffect-of-environmental-education-on-environmental-5520

[51] Abdullah, S., I., S., S. Extending the concept of pro-environmental action and behaviour: A binary perspective. Environmental Education Research. 26(12), 1764-1786, 2019, https://doi.org/10.1080/13504622.2020.1850645 
[52] Cao, Q. A comparative study on the development status of environmental education in the United States, the United Kingdom, and Australia. IOP Conference Series: Earth and Environmental Science, 576, 1-10, 2020, https://doi.org/10.1088/1755-1315/576/1/012008

[53] Ardoin, N., M., Bowers, A., W., Gaillard, E. Environmental education outcomes for conservation: A systematic review. Biological Conservation, 241, 2020, https://doi.org/10.1016/j.biocon.2019.108224

[54] Yuan, W., Shih, K., T., and Lin, C., J. Research on the integration of inquiry-based approach into the environmental education of sustainable development. IOP Conference Series: Earth and Environmental Science, 576, 1-9, 2020, https://doi.org/10.1088/1755$1315 / 576 / 1 / 012012$

[55] Arinushkina, A., A. Environmental education for sustainable development: Perspectives from Russia. IOP Conference Series: Earth and Environmental Science, 274, 1-5, 2019, https://doi.org/10.1088/1755-1315/274/1/012138

\section{$7 \quad$ Authors}

Desy Safitri is a lecturer from the Social Studies Education study program, Faculty of Social Science, Universitas Negeri Jakarta, Jakarta, Indonesia. She is also a chief of this study program.

Ika Lestari is a lecturer from the Elementary School Teacher Education study program, Faculty of Education, Universitas Negeri Jakarta, Jakarta, Indonesia. She is also an evaluator for opening study programs at the Ministry of Research, Technology, and the Higher Education Republic Indonesia.

Arifin Maksum is a lecturer from the Elementary School Teacher Education study program, Faculty of Education, Universitas Negeri Jakarta, Indonesia. He is an assessor at the national accreditation body for higher education at the Ministry of Education and Culture Republic Indonesia.

Nurzengky Ibrahim is a lecturer from the History Education study program, Faculty of Social Science, Universitas Negeri Jakarta, Indonesia. His main research interest is related to education.

Arita Marini is a lecturer from the Elementary School Teacher Education study program, Faculty of Education, Universitas Negeri Jakarta, Jakarta, Indonesia. She is also an assessor at the national accreditation body for higher education at the Ministry of Education and Culture Republic Indonesia.

Musril Zahari is a lecturer from Sekolah Tinggi Ilmu Ekonomi, Jakarta, Indonesia. His main research interest is related to education. He has done some research with colleagues at Universitas Negeri Jakarta.

Rossi Iskandar is a lecturer from the Elementary School Teacher Education study program, Faculty of Education, Universitas Trilogi, Jakarta, Indonesia. He is studying at Universitas Negeri Jakarta to get a doctoral degree.

Article submitted 2021-02-13. Resubmitted 2021-03-20. Final acceptance 2021-03-20. Final version published as submitted by the authors. 